\title{
Bench Test for the Detection of Bacterial Contamination in Platelet Concentrates Using Rapid and Cultural Detection Methods with a Standardized Proficiency Panel
}

\author{
Tanja Vollmer $^{\mathrm{a}}$ Cornelius Knabbe ${ }^{\mathrm{a}}$ Wolf-Jochen Geilenkeuser ${ }^{\mathrm{b}}$ Michael Schmidt ${ }^{\mathrm{c}}$ \\ Jens Dreier ${ }^{\mathrm{a}}$ \\ ${ }^{a}$ Institute for Laboratory and Transfusion Medicine, Heart and Diabetes Center North Rhine Westphalia, Bad Oeynhausen, Germany; \\ ${ }^{b}$ Reference Institute for Bioanalytics, Bonn, Germany; \\ c Institute of Transfusion Medicine and Immunohematology, German Red Cross, Johann Wolfgang Goethe University, \\ Frankfurt/M., Germany
}

\section{Keywords}

Collaborative trial · Platelet bacteria screening .

BactiFlow · NAT · Rapid methods

\section{Summary}

Background: The most frequent infectious complication in transfusion therapy in developed countries is related to the bacterial contamination of platelet concentrates (PCs). Rapid and cultural screening methods for bacterial detection in platelets are available, but external performance evaluation, especially of rapid methods, has been difficult to realize so far. Here we summarize the results of three individual collaborative trials using an external quality assessment program (EQAP) for the application of current rapid and cultural screening methods. Methods: Three different modules were available for the detection of bacterial contamination: module 1: rapid methods, module 2: culture methods, module 3: bacterial identification methods. The sample set-up included up to six different bacterial strains, 1-2 negative samples and 4-6 positive samples with stabilized bacterial cell counts (approximately $10^{3} / 10^{4} / 10^{5} \mathrm{CFU} / \mathrm{ml}$ ). Time schedule for testing was limited (module 1: $6 \mathrm{~h}$, module 2 and 3: 7 days). Results: Samples of module 1 were analyzed with two different rapid methods (BactiFlow, NAT). The results of the three individual collaborative trials showed that all participants detected the negative samples with both assays correctly. Samples spiked with $10^{4}$ to $10^{5}$ $\mathrm{CFU} / \mathrm{ml}$ of bacteria obtained positive results with both rapid screening methods, whereas samples spiked with only $10^{3} \mathrm{CFU} / \mathrm{ml}$ disclosed a lower number of correctly identified positive results by NAT (86.6-93.8\% sensitivity) compared to BactiFlow ( $100 \%$ sensitivity). The results for modules 2 and 3 revealed a 100\% diagnostic sensitivity and specificity in all three collaborative trials. Conclusion: This proficiency panel facilitates the verification of the analytical sensitivity of rapid and cultural bacterial detection systems under controlled routine conditions. The concept of samples provided in this EQAP has three main advantages: i) samples can be examined by both rapid and culture methods, ii) the provided material is matrix-equivalent, and iii) the sample material is ready-to-use.

(c) 2015 S. Karger GmbH, Freiburg

\section{Introduction}

In developed countries, the residual risk of transfusion-related bacterial infections is currently 10 - to 100 -fold higher than the residual risk of virus infections (e.g. HIV-1, HCV or HBV [1]). The major difference between contamination by viruses and bacteria is that even extremely small numbers of bacteria can multiply to vast and clinically dangerous levels, especially in platelet concentrates (PCs) during their storage period under usual PC storage conditions at $22-24^{\circ} \mathrm{C}$ [2]. German hemovigilance data showed that severe transfusion reactions, especially with PCs, often occurred at the end of their storage period [3]. In 2008, the maximum shelf life

\section{KARGER}

Fax +497614520714

\section{(c) 2015 S. Karger GmbH, Freiburg}

$1660-3796 / 15 / 0424-0220 \$ 39.50 / 0$ 
Table 1. Potential target values of the collaborative trial and options for participation

\begin{tabular}{llll}
\hline & Principle & Result & Applicable methods \\
\hline $\begin{array}{l}\text { Module } 1 \\
\text { rapid detection methods }\end{array}$ & $\begin{array}{l}\text { bacterial detection, } \\
\text { qualitative }\end{array}$ & positive or negative & $\begin{array}{l}\text { BactiFlow } \\
16 S / 23 S \text { rDNA } \\
\text { PGD }^{*}, \text { BacTx }^{*}\end{array}$ \\
\hline $\begin{array}{l}\text { Module 1 } \\
\text { rapid detection methods }\end{array}$ & $\begin{array}{l}\text { bacterial detection, } \\
\text { quantitative }\end{array}$ & $\begin{array}{l}\text { positive or negative, } \\
\text { determination CFU/ml }\end{array}$ & $\begin{array}{l}\text { BactiFlow } \\
16 S / 23 S \text { rDNA }\end{array}$ \\
\hline $\begin{array}{l}\text { Module 2 } \\
\text { culture detection methods (CULT DT) }\end{array}$ & $\begin{array}{l}\text { bacterial detection, } \\
\text { qualitative }\end{array}$ & positive or negative & BacT/ALERT, Bactec \\
\hline $\begin{array}{l}\text { Module 3 } \\
\text { culture detection methods (CULT ID) }\end{array}$ & identification of bacteria & $\begin{array}{l}\text { determination of bacterial } \\
\text { species }\end{array}$ & BacT/ALERT, Bactec \\
\hline \begin{tabular}{l}
$*$ To be determined before use. \\
\hline
\end{tabular} & & & \\
\hline
\end{tabular}

for PCs without treatment for pathogen reduction was reduced in Germany from 5 to 4 days to increase blood safety (Vote 38, German Blood Advisory Board [4]). However, the shelf life may be prolonged back to 5 days if pathogen reduction or adequate bacterial detection is implemented [4]. At the moment, two rapid bacterial detection systems (BactiFlow (BF; bioMérieux, Nuertingen, Germany) and 16S DNA NAT (German Red Cross, Frankfurt/M., Germany [5]) have been accepted by the German authority (PaulEhrlich-Institut (PEI), Langen, Germany) to enable extension of PC shelf life to 5 days [5-7]. Nevertheless, the validation and assessment of bacterial screening methods in a consistent manner is a laborious and complicated process. The establishment of the WHO Repository of Platelet Transfusion-Relevant Bacteria Reference Strains (TRBRS) by the Subgroup on Bacteria of the Working Party on Transfusion-Transmitted Infectious Diseases of the International Society Blood Transfusion (ISBT) was considered as a first step in the implementation of a relevant bacterial reference material [8]. These standards contained deep-frozen bacterial suspensions defined in bacterial species and bacterial cell count with a guaranteed ability to proliferate in PCs [8]. A second innovation could be the development of a proficiency panel with stabilized bacterial cell counts for the head-to-head comparison of methods for the detection of bacterial contamination in PCs [9]. In the present study, we demonstrate the suitability of a recently developed proficiency panel by presenting the results from three independent collaborative trials.

\section{Material and Methods}

\section{PC Collection and Bacterial Strains}

Apheresis-derived single-donor PCs (APCs) were prepared in the transfusion service Uni.Blutspendedienst OWL (Bad Oeynhausen, Germany) after standard processing with the Haemonetics MCS+ $\left(2.0-4.0 \times 10^{11}\right.$ platelets/unit (205-295 ml); Haemonetics GmbH, Munich, Germany). PCs were stored in gas-permeable containers (LN994CF-CPP; Haemonetics GmbH) at $20-24{ }^{\circ} \mathrm{C}$ under constant agitation. APCs were used for all samples included in the first collaborative trial (BAK TK 2_2013).

Pooled PCs (PPCs) were prepared according to the procedure routinely used at the Frankfurt German Red Cross institute [5]. After preparation, PPCs contained $2.0 \times 10^{11}$ platelets/unit. PPCs were used for all samples included in the second and third collaborative trial (BAK TK 1_2014 and BAK TK 2_2014).
Strains of Bacillus cereus ATCC 11778 and Escherichia coli ATCC 25922 were purchased from the American Type Culture Collection (ATCC; LGC Promochem GmbH, Wesel, Germany). Strains of Staphylococcus aureus PEI-B23-04, Staphylococcus epidermidis PEI-B-06-06 (conform to TRBRS PEI-BP-06), Klebsiella pneumoniae PEI-B-08-08 (conform to TRBRS PEI-B-P-08) and Streptococcus pyogenes PEI-B-20-05 (conform to TRBRS PEI-B-P-20) were obtained from the PEI.

\section{Study Design}

This study comprised an inter-laboratory comparison regarding the detection of bacterial contamination in PCs using rapid detection methods (BF, NAT, module 1, table 1) or cultural detection and identification methods (module 2 and 3, table 1) for the proof of bacterial contamination in PCs. Participants were asked to identify the blinded samples following their routine laboratory protocols. The sample set-up included up to six different bacterial strains, two negative samples and 4-6 positive samples with different stabilized bacterial cell counts (approximately $10^{3} / 10^{4} / 10^{5} \mathrm{CFU} / \mathrm{ml}$ ). Participants will pass the proficiency panel using rapid detection methods (module 1) if negative samples have negative results and positive samples have positive results; samples spiked with bacteria in the range of $10^{5} \mathrm{CFU} / \mathrm{ml}$ must have positive results, samples with low concentrations should have positive results, depending on the rapid detection method used. Participants will pass the proficiency panel using cultural detection and identification methods (module 2 and 3 ) if negative samples have negative results and positive samples have positive results and all strains are correctly identified.

\section{Sample Preparation for the Collaborative Trial}

Baseline sterility of PCs was determined by inoculation of aerobic and anaerobic culture bottles (BacT/Alert BPA/BPN; bioMérieux) with $5 \mathrm{ml}$ of PC sample. Culture bottles were incubated at $37^{\circ} \mathrm{C}$ in the BacT/Alert automated culture system for 7 days. Overnight-grown cultures in tryptone soy broth of different bacteria (table 2) were used for inoculation of PC samples. Bacterial counts were semi-quantitatively enumerated using the BF assay to assess a rough estimation of volumes required for inoculation with the specified cell counts. Subsequently, bacterial cell counts were adjusted in PCs (target values, table 2). An antibiotic concentration of $10 \mu \mathrm{g} / \mathrm{ml}$ cotrimoxazole (trimethoprim: sulfo-methoxazole 1:5) was added to each sample to prevent bacterial growth. Samples were blinded with a random order for each screening method (rapid detection methods vs. cultural screening) and were sent overnight to participants in temperature-controlled boxes (range $4-8{ }^{\circ} \mathrm{C}$; Eutecma, Mannheim, Germany). The next day, samples were maintained at room temperature for $1 \mathrm{~h}$ prior to analysis. All participants started sample analysis between 8 and 9 a.m. The time schedule for testing with rapid detection methods was limited to $6 \mathrm{~h}$ to avoid falsification of results e.g. by application of pre-incubation steps. The time schedule for testing with cultural detection methods was limited to 7 days.

Previously, all bacterial strains used in the collaborative trials were shown to be sufficient for the proficiency panel by determination of the stability of bacte- 
Table 2. Results of the three independent collaborative trials

\begin{tabular}{|c|c|c|c|c|c|}
\hline Sample & Target value (CFU/ml) & $\mathrm{BF}$ & NAT & CULT DT & CULT ID \\
\hline \multicolumn{2}{|c|}{ BAK TK 2_2013 } & $n=3$ & $n=4$ & $n=5$ & $n=2$ \\
\hline S1 & negative & $3 / 3$ & $4 / 4$ & $5 / 5$ & $2 / 2$ \\
\hline S2 & S. aureus $\left(3.63 \times 10^{3}\right)$ & $3 / 3$ & $3 / 4(\mathrm{~A})^{*}$ & $5 / 5$ & $2 / 2$ \\
\hline S3 & negative & $3 / 3$ & $4 / 4$ & $5 / 5$ & $2 / 2$ \\
\hline S4 & K. pneumoniae $\left(1.90 \times 10^{5}\right)$ & $3 / 3$ & $4 / 4$ & $5 / 5$ & $2 / 2$ \\
\hline S5 & E. coli $\left(8.33 \times 10^{2}\right)$ & $3 / 3$ & $4 / 4$ & $5 / 5$ & $2 / 2$ \\
\hline S6 & S. epidermidis $\left(2.37 \times 10^{5}\right)$ & $3 / 3$ & $4 / 4$ & $5 / 5$ & $2 / 2$ \\
\hline \multicolumn{2}{|c|}{ Sensitivity (\%) } & 100 & 93.8 & 100 & 100 \\
\hline \multicolumn{2}{|c|}{ Specificity $^{* *}(\%)$} & 100 & 100 & 100 & - \\
\hline \multicolumn{2}{|c|}{ BAK TK 1_2014 } & $n=4$ & $n=5$ & $n=15$ & $n=2$ \\
\hline S1 & negative & $4 / 4$ & $5 / 5$ & $15 / 15$ & $2 / 2$ \\
\hline S2 & S. epidermidis $\left(5.31 \times 10^{3}\right)$ & $4 / 4$ & $4 / 5(\mathrm{~A})^{*}$ & $15 / 15$ & $2 / 2$ \\
\hline S3 & E. $\operatorname{coli}\left(2.71 \times 10^{5}\right)$ & $4 / 4$ & $5 / 5$ & $15 / 15$ & $2 / 2$ \\
\hline S4 & S. aureus $\left(5.47 \times 10^{4}\right)$ & $4 / 4$ & $5 / 5$ & $15 / 15$ & $2 / 2$ \\
\hline S5 & B. cereus $\left(3.50 \times 10^{5}\right)$ & $4 / 4$ & $5 / 5$ & $15 / 15$ & $2 / 2$ \\
\hline S6 & K. pneumoniae $\left(2.05 \times 10^{3}\right)$ & $4 / 4$ & $4 / 5(\mathrm{~A})^{*}$ & $15 / 15$ & $2 / 2$ \\
\hline S7 & negative & $4 / 4$ & $5 / 5$ & $15 / 15$ & $2 / 2$ \\
\hline S8 & S. pyogenes $\left(2.25 \times 10^{4}\right)$ & $4 / 4$ & $5 / 5$ & $15 / 15$ & $2 / 2$ \\
\hline \multicolumn{2}{|c|}{ Sensitivity (\%) } & 100 & 93.3 & 100 & 100 \\
\hline \multicolumn{2}{|c|}{ Specificity (\%) } & 100 & 100 & 100 & - \\
\hline \multicolumn{2}{|c|}{ BAK TK 2_2014 } & $\mathrm{n}=4$ & $\mathrm{n}=3$ & $\mathrm{n}=16$ & $n=7$ \\
\hline S1 & E. coli $\left(4.60 \times 10^{4}\right)$ & $4 / 4$ & $3 / 3$ & $16 / 16$ & $7 / 7$ \\
\hline S2 & S. epidermidis $\left(3.10 \times 10^{4}\right)$ & $4 / 4$ & $3 / 3$ & $16 / 16$ & $7 / 7$ \\
\hline S3 & S. aureus $\left(8.63 \times 10^{5}\right)$ & $4 / 4$ & $3 / 3$ & $16 / 16$ & $7 / 7$ \\
\hline S4 & S. aureus $\left(3.55 \times 10^{4}\right)$ & $4 / 4$ & $3 / 3$ & $16 / 16$ & $7 / 7$ \\
\hline S5 & negative & $4 / 4$ & $3 / 3$ & $16 / 16$ & $7 / 7$ \\
\hline S6 & E. coli $\left(9.33 \times 10^{2}\right)$ & $4 / 4$ & $1 / 3(\mathrm{~A}, \mathrm{~B})^{*}$ & $16 / 16$ & $7 / 7$ \\
\hline \multicolumn{2}{|c|}{ Sensitivity (\%) } & 100 & 86.6 & 100 & 100 \\
\hline \multicolumn{2}{|c|}{ Specificity (\%) } & 100 & 100 & 100 & - \\
\hline
\end{tabular}

rial cell counts between sample set-up and execution of analysis (data not shown). Susceptibility of bacteria included in the proficiency panel against cotrimoxazole was determined using the Vitek II system (bioMérieux).

In addition to the samples of the collaborative trial, our institute further analyzed samples with BF [7], NAT [10], and cultural methods [11] directly after processing to monitor the influence of transportation on bacterial cell counts. Furthermore, bacterial cell counts were determined at each sampling point by plating $100 \mu \mathrm{l}$ aliquots of serial dilutions of PC samples in triplicate onto tryptone soy agar (colony-forming assay). Plates were incubated at $37^{\circ} \mathrm{C}$ for a maximum of $48 \mathrm{~h}$, followed by counting of the number of colonies and calculation of the bacterial cell counts per milliliter (CFU/ml).

\section{Statistical Analysis}

All values are given as mean values ( \pm standard deviation $(\mathrm{SD}))$. Mean values and SD were calculated using the GraphPad Prism 4.0 software (GraphPad Software, San Diego, CA, USA).

\section{Results}

Results of Rapid Detection Methods (Module 1)

The data received from three independent collaborative trials (BAK TK 2_2013, 1_2014, 2_2014) included 3-4 participants using
BF flow cytometric analysis and 3-5 participants using NAT methods, including our institute (table 2). All participants detected the negative samples with both assays correctly, resulting in a diagnostic specificity of $100 \%$. Samples spiked with bacteria in the range of $10^{4}-10^{5} \mathrm{CFU} / \mathrm{ml}$ obtained positive results with both rapid screening methods. The BF assay also correctly detected samples spiked with bacterial cell counts in the range of $10^{3} \mathrm{CFU} / \mathrm{ml}$, resulting in a diagnostic sensitivity of $100 \%$. NAT testing showed a lower number of correctly identified positive results (56/61 samples). Samples inoculated with $3.63 \times 10^{3} \mathrm{CFU} / \mathrm{ml}$ S. aureus (BAK TK 2_2013), $5.31 \times 10^{3} \mathrm{CFU} / \mathrm{ml}$ S. epidermidis, $2.05 \times 10^{3} \mathrm{CFU} / \mathrm{ml} \mathrm{K}$. pneumoniae (BAK TK 1_2014) and $9.33 \times 10^{2} \mathrm{CFU} / \mathrm{ml}$ E. coli (BAK TK 2_2014) showed negative results, resulting in a lower diagnostic sensitivity of $86.6-93.8 \%$. For all samples deviating from the respective target values, NAT testing was performed by the same laboratories (A and B, table 2).

Quantitative BF values revealed a good concordance among all participants and indicated a good correlation compared to target values (fig. 1). Quantitative detection of bacteria using NAT methods was not performed by any participant so far. 


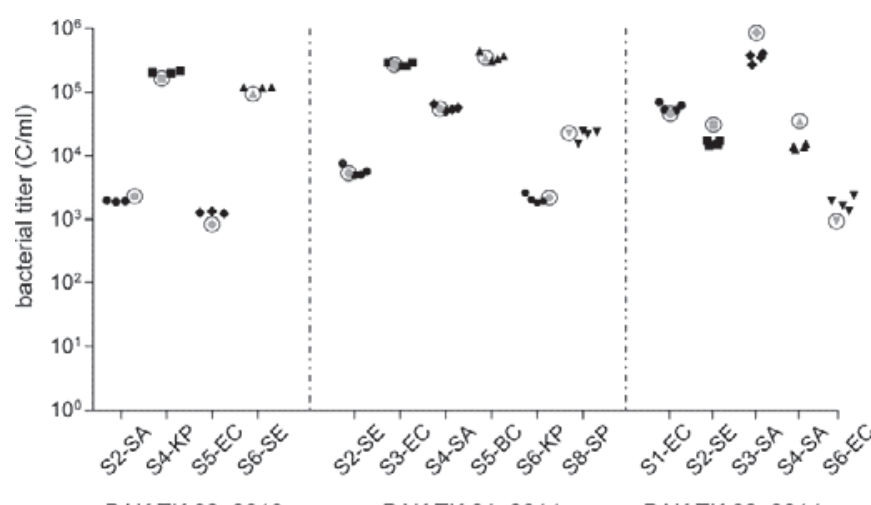

BAK TK 022013

BAK TK 022014

Fig. 1. Results of the semi-quantitative $B F$ analysis. The target values for the respective samples according to table 2 are displayed as grey-shaded and encircled. Samples were arranged in connection with the respective collaborative trial (BAK TK 02_13, BAK TK 01_14, BAK TK 02_14, table 2), sample description were shortened with specification of the sample number and the contaminating bacterium (e.g. S2-SA: sample 2, contaminated with $S$. aureus). $\mathrm{BC}=B$. cereus; $\mathrm{EC}=$ E. coli $; \mathrm{KP}=$ K. pneumoniae $; \mathrm{SA}=$ S. aureus $; \mathrm{SE}=$ S. epidermidis; $\mathrm{SP}=\mathrm{S}$. pyogenes.

\section{Results of Cultural Detection Methods and Identification}

Methods of Bacteria (Modules 2 and 3)

The data received from three independent collaborative trials included 5-16 participants for module 2 and 2-7 participants for module 3, including our institute (table 2). The application of culture methods for detection and identification of bacteria revealed a diagnostic sensitivity and specificity of $100 \%$; all participants correctly detected and identified the samples inoculated with transfusion-relevant bacteria.

\section{Stability of Test Results}

A comparison of pre- and post-transportation characteristics was additionally performed at our institute in order to confirm that neither inoculation with overnight-grown cultures nor shipping conditions had an effect on the outcome. Analysis by $23 \mathrm{~S}$ rDNA real-time NAT revealed concordant positive and negative results before and after transportation (data not shown). Figure 2 displays the analysis of positive samples by BF and colony-forming assay, as well as analysis by the BacT/Alert system before and after transportation.

The results obtained by semi-quantitative BF analysis provided almost equal bacterial counts in positive samples prior to and post transportation. Furthermore, counts demonstrated a good correlation to values determined by colony-forming assay. Bacterial counts determined by colony-forming assay prior to transportation were also in accordance with counts determined after transportation, with the exception of samples inoculated with $<10^{5} \mathrm{CFU} / \mathrm{ml}$ E. coli (BAK TK 2_2013 S5, BAK TK 2_2014 S1 and S6). For those samples, cell counts were reduced by $0.5 \log$ values (fig. 2).

Cultural detection times did not considerably differ between pre- and post-transportation analysis ( $\Delta$ pre/post $<2 \mathrm{~h}$ ), with the exception of the samples inoculated with less than $5 \mathrm{ml}$ inoculation volume (BAK TK 1_14 S8 and BAK TK 2_14 S1).

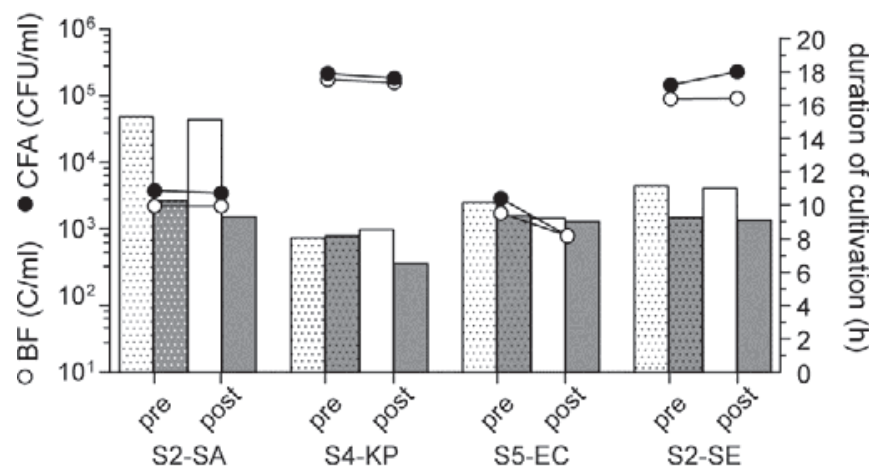

RV BAK TK 1_2014

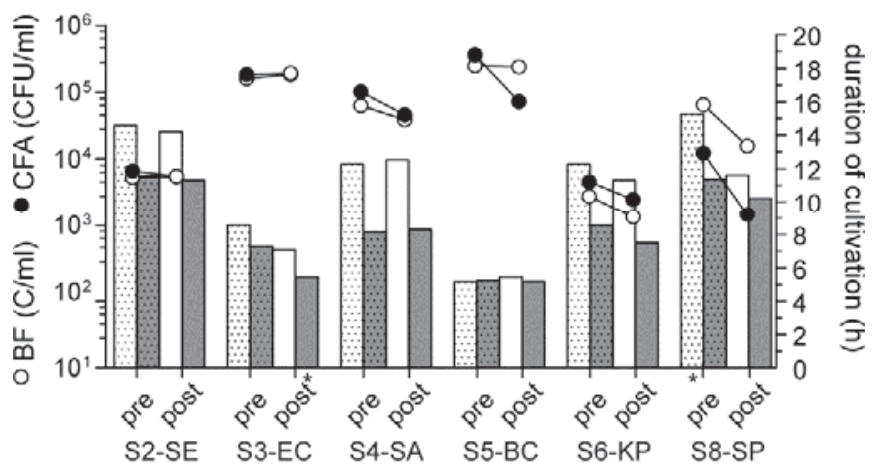

RV BAK TK 2_2014

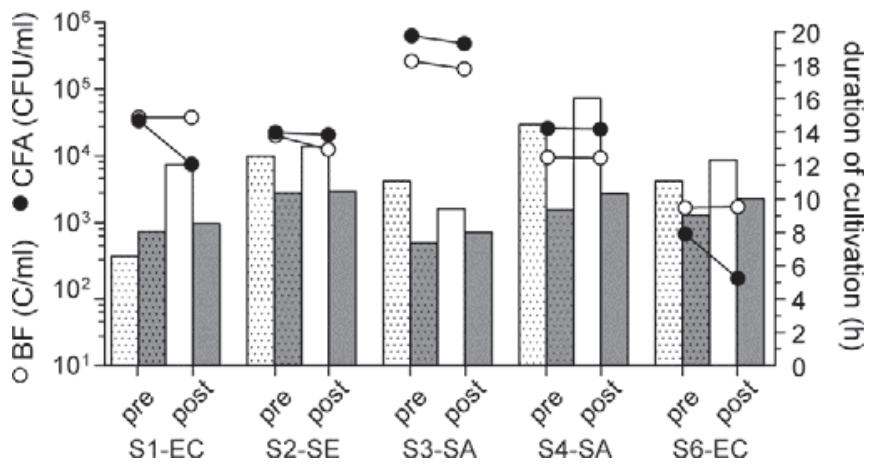

Fig. 2. Comparison of bacterial cell counts before and after transportation during the three collaborative trials. The influence of storage conditions on bacterial cell counts and growth kinetics was monitored by BF flow cytometry $(\mathrm{C} / \mathrm{ml})$ and colony-forming assay (CFA, $\mathrm{CFU} / \mathrm{ml}$ ) and by the duration of cultivation (white bar: aerobic culture, grey bar: anaerobic culture). ${ }^{*}$ Samples inoculated with less than $5 \mathrm{ml}$ sample volume. $\mathrm{S}=$ Sample; $\mathrm{BC}=$ B. cereus; $\mathrm{EC}=$ E. coli $\mathrm{KP}=$ K. pneumoniae $; \mathrm{SA}=$ S. aureus; $\mathrm{SE}=$ S. epidermidis; $\mathrm{SP}=$ S. pyogenes.

\section{Discussion}

Two rapid screening methods based on amplification of $16 \mathrm{~S}$ rDNA and BF flow cytometry are currently accepted in Germany for the extension of the PC storage period from 4 to 5 days [5-7]. Therefore, verification of the sensitivity, performance, and effi- 
ciency of prominently applied rapid screening methods should be continuously proven by independent proficiency panels. Ideally, External quality assessment programs (EQAPs) as they are known for viral parameters should be available since application of these programs has been shown to be an effective tool for quality assurance. In contrast to viruses, bacteria are capable of growing in PCs during transportation of samples to participants. This could result in variable cell counts, preventing an objective comparison of the sensitivity of bacterial screening methods. Therefore, the establishment of an adequate EQAP poses some considerable challenges. For example, deep frozen storage of samples is not an option since some detection principles require an active bacterial metabolism (e.g. BF [12]). Furthermore, EQAP panels should contain matrix-equivalent samples to effectively review different methods.

However, the availability of transfusion-relevant bacteria reference material is limited. One achievement in the past was the establishment of the WHO-TRBRS, containing deep-frozen bacterial suspensions defined for bacterial species and cell count [8]. The TRBRS are intended for the validation and comparison of detection and pathogen reduction methods by using on the one hand low bacterial spiking and proliferation during storage and on the other hand defined bacterial cell counts by diluting and measurement. These standards implicate the following advantages: i) quality, stability and suitability for defined low-titer spiking of blood components and ii) the property of bacterial proliferation to high counts in PCs from donors in different regions of the world [8]. Certainly, these standards cannot be used to assess our requirements of the collaborative trial. An effective head-to-head-comparison demanded for defined sample material (matrix-equivalent samples with stabilized bacterial cell counts) to provide identical starting positions for each participant. Deep frozen cultures of the TRBRS were initially required to be inoculated into a PC matrix. This step includes a manipulation potential for participants as well as inter-laboratory differences of bacterial growth kinetics due to varying incubation times and/or PC matrix effects, impeding equal starting positions for each participant.

Therefore, we complementary developed the proficiency panels provided in this EQAP to guarantee the following three points: i) samples can be examined by both rapid and culture methods; ii) the provided materials are matrix-equivalent since PCs were used for inoculation with bacteria; and iii) the sample material is readyto-use, prohibiting external manipulation. Certainly, the concept of addition of antibiotics and decrease in temperature storage does not reflect the environmental situation of bacterial contamination. However, the EQAP panels were not intended to deal with simulation of real-life conditions and the interventions showed no influence on the outcome. The addition of antibiotics, as well as limitation of time schedule for testing with rapid detection methods, is essential to effectively prevent changes in bacterial cell counts and manipulation of the outcome, e.g. by previous incubation of samples to induce bacterial proliferation,

Cotrimoxazole is a bacteriostatic antibiotic and inhibits bacterial DNA synthesis. Storage conditions showed a limited influence on bacterial cell counts in some samples inoculated with Gramnegative bacteria (reduction by approximately $0.5 \mathrm{log}$ values) obtained by colony-forming assay. The storage condition might influence the stability of bacterial cell walls and bacterial biosynthesis, most likely resulting in i) higher susceptibility to mechanical stress and ii) extended lag phase. Though, consideration of this aspect is also not necessary in relation to the recent concept of the collaborative trial since no influence on the result outcome of rapid detection methods was observed. In our opinion, this is an acceptable compromise to ensure the stabilization of bacterial count for sample distribution and the prevention of manipulatory efforts.

The aspect of bacterial growth matrix should also be discussed since we used overnight cultures for inoculation of samples rather than bacteria grown in PCs. Cultivation of bacteria in growth-optimized media might provoke the expression of other biological properties (e.g. capsule, exopolysaccharides, antigens) compared to cultivation in a complex matrix such as PCs [8]. Strain-dependent behavior in platelets may have influence in the different detection settings, potentially resulting in unreliable results, e.g. using imaging instruments. However, it was demonstrated that currently used bacterial strains are capable to grow in PCs $[8,12,13]$. The comparison of results obtained with overnight grown cultures was proven to have no influence on the stability of bacterial cell counts and the result outcome. Therefore, consideration of the aspect of growth matrix is not necessary for the strains used in this study and the concept of the collaborative trial. Furthermore, samples of this collaborative trial were either prepared using APCs (BAK-TK 2_2013) or PPCs (BAK-TK 1_2014, BAK-TK 2_2014), revealing no differences in the result analysis.

The results from the three individual collaborative trials using rapid detection methods disclosed that the BF assay currently had a higher sensitivity to detect bacterial contamination compared to NAT screening. Interestingly, the limit of detection (LOD) of the NAT is determined to be $35 \mathrm{CFU}$ (95\% CI 12-155 CFU/ml, [5]), revealing a discrepancy by a factor of approximately 10 to 100 regarding the determined cell counts of the non-detected collaborative trial samples (range $9.33 \times 10^{2}$ to $5.31 \times 10^{3} \mathrm{CFU} / \mathrm{ml}$ ). Determination of the LOD is an important criterion for the evaluation of an analytical method [14]. Standards for validation experiments are often produced by each laboratory individually due to the absence of adequate reference materials. Particularly, comparison between the LODs of different bacterial NAT assays is difficult since varying amounts of non-cultivable dead cells or free nucleic acids that can be amplified by NAT assays, and the variation in the number of gene copies in a given bacterial species, complicate bacterial quantitation by real-time PCR assays [14]. Hence, especially the sensitivity of NAT methods, but also that of all other screening methods, was verifiable using proficiency panels and EQAPs. Quantification of the overall cell count by BF flow cytometry revealed a good inter-laboratory concordance, demonstrating the feasibility of the provided sample material for quantitative purposes. Since quantitative determination of bacterial counts by BF flow cytometry also exhibited a good correlation to counts determined by colony-forming assay in the present study and in the past 
$[7,9,11,12,15,16]$, determination of bacterial counts exclusively by flow cytometry would be a possible option.

The applicability of other common rapid methods (e.g. PGD, $\mathrm{BacTx}$ ) needed to be proven prior to first-time application of these methods by other participants. Since the PGD assay was recommended by the American Association of Blood Banks (standard (5.1.5.1.1) as an optional way of meeting the criteria for bacterial screening of PCs [17], this assay has been evaluated in various studies in the USA as a rapid assay for routine screening of PCs $[18,19]$. Nevertheless, we are convinced that the addition of antibiotics should not interfere with the test principle, and previous experiences have ultimately shown that the reduction in storage temperature had no influence on the assay results [9].

Unfortunately, the result submission form for the different modules so far does not mandatorily request information regarding the performed NAT testing (16SrDNA, 23SrDNA), the automated culture systems, and bacterial identification methods used. In order to reach more targeted statements, we will include this query in further quality assurance programs for all modules.

The collaborative testing proved successful for the three offered modules. The head-to-head comparison demonstrated a good per- formance of both rapid systems currently accepted by the PEI, with a slight advantage of the BF assay. Regular successful participation in proficiency testing confirms the efficiency of the analytical sensitivity and all processes of bacterial screening methods under routine conditions. Based on the situation that contamination of blood components with harmful bacterial strains is a rare event (estimated at 1:100,000), prohibiting routine-controlled evaluation of methods along the way, a regular participation in proficiency panels to survey bacterial screening methods represents an important contribution to blood safety.

\section{Acknowledgements}

The authors thank Sarah Kirkby for her linguistic advice. Furthermore, we thank Dr. Mareike Dabisch-Ruthe, Bärbel Kammel, and Birgit Drawe for their technical assistance.

\section{Disclosure Statement}

All authors state that they have no potential conflict of interest.

\section{References}

1 Janetzko K, Schmidt M: Shelf life extension of platelet concentrates from four to five days. Transfusionsmedizin 2015;5:27-30.

2 Montag T: Perspectives and limitations in the bacterial screening of platelet concentrates. J Lab Med 2006;30: $60-65$.

3 Funk MB, Lohmann A, Guenay S, Henseler O, Heiden M, Hanschmann KM, Keller-Stanislawski B: Transfusion-transmitted bacterial infections - haemovigilance data of German blood establishments (1997-2010). Transfus Med Hemother 2011;38:266-271.

4 Arbeitskreis Blut: Votum 38: Festlegung der Halt barkeitsfrist von Thrombozytenkonzentraten mit dem Ziel der Reduktion lebensbedrohlicher septischer Transfusionsreaktionen durch bakterielle Kontamination. Bundesgesundheitsblatt 2008;51:1484.

5 Sireis W, Ruster B, Daiss C, Hourfar MK, Capalbo G, Pfeiffer HU, Janetzko K, Goebel M, Kempf VA, Seifried E, Schmidt M: Extension of platelet shelf life from 4 to 5 days by implementation of a new screening strategy in Germany. Vox Sang 2011;101:191-199.

6 Müller B, Walther-Wenke G, Kalus M, Alt T, Bux J, Zeiler T, Schottstedt V: Routine bacterial screening of platelet concentrates by flow cytometry and its impact on product safety and supply. Vox Sang 2015; 108: 209-218..

7 Vollmer T, Engemann J, Kleesiek K, Dreier J: Bacterial screening by flow cytometry offers potential for extension of platelet storage: results of 14 months of active surveillance. Transfus Med 2011;21:175-182.
8 Störmer M, Arroyo A, Brachert J, Carrero H, Devine D, Epstein JS, Gabriel C, Gelber C, Goodrich R, Hanschmann KM, Heath DG, Jacobs MR, Keil S, de Korte D, Lambrecht B, Lee CK, Marcelis J, Marschner S, McDonald C, McGuane S, McKee M, Muller TH, Muthivhi T, Pettersson A, Radziwon P, Ramirez-Arcos S, Reesink HW, Rojo J, Rood I, Schmidt M, Schneider CK, Seifried E, Sicker U, Wendel S, Wood EM, Yomtovian RA, Montag T: Establishment of the first International Repository for Transfusion-Relevant Bacteria Reference Strains: ISBT Working Party TransfusionTransmitted Infectious Diseases (WP-TTID), Subgroup on Bacteria. Vox Sang 2012;102:22-31.

9 Vollmer T, Hinse D, Schottstedt V, Bux J, Tapernon K, Sibrowski W, Knabbe C, Dreier J: Inter-laboratory comparison of different rapid methods for the detection of bacterial contamination in platelet concentrates. Vox Sang 2012;103:1-9.

10 Störmer M, Kleesiek K, Dreier J: High-volume extraction of nucleic acids by magnetic bead technology for ultrasensitive detection of bacteria in blood components. Clin Chem 2007;53:104-110.

11 Vollmer T, Schottstedt V, Bux J, Walther-Wenke G, Knabbe C, Dreier J: Bacterial screening of platelet concentrates on day 2 and 3 with flow cytometry: the optimal sampling time point? Blood Transfus 2014;12: 388-395.

12 Dreier J, Vollmer T, Kleesiek K: Novel flow cytometrybased screening for bacterial contamination of donor platelet preparations compared with other rapid screening methods. Clin Chem 2009;55:1492-1502.
3 Vollmer T, Hinse D, Kleesiek K, Dreier J: The Pan Genera Detection immunoassay: a novel point-of-issue method for detection of bacterial contamination in platelet concentrates. J Clin Microbiol 2010;48:34753481.

14 Dreier J, Störmer M, Kleesiek K: Real-time polymerase chain reaction in transfusion medicine: applications for detection of bacterial contamination in blood products. Transfus Med Rev 2007;21:237-254.

15 Vollmer T, Dreier J, Schottstedt V, Bux J, Tapernon K, Sibrowski W, Kleesiek K, Knabbe C: Detection of bacterial contamination in platelet concentrates by a sensitive flow cytometric assay (BactiFlow): a multicentre validation study. Transfus Med 2012;22:262-271.

16 Vollmer T, Knabbe C, Dreier J: Novel flow cytometric screening method for bacterial contamination of red blood cells: a proof-of-principle evaluation. Transfusion 2014;54:900-909.

17 Association Bulletin: Association Bulletin \#10-02: Interim Standard 5.1.5.1.1. AABB 20102010.

18 Harm SK, Delaney M, Charapata M, Aubuchon JP, Triulzi DJ, Yazer MH: Routine use of a rapid test to detect bacteria at the time of issue for nonleukoreduced, whole blood-derived platelets. Transfusion 2013;53:843-850.

19 Jacobs MR, Smith D, Heaton WA, Zantek ND, Good CE: Detection of bacterial contamination in prestorage culture-negative apheresis platelets on day of issue with the Pan Genera Detection test. Transfusion 2011; 51:2573-2582. 